\title{
MANAGEMENT OF TAX PAYMENTS UNDER THE DEFINITIVE VALUE ADDED TAX REGIME
}

\author{
Māris JURUŠS ${ }^{1}$, Girts FELDBERGS ${ }^{2}$ \\ ${ }^{1,2}$ Riga Technical University, Riga, Latvia \\ Corresponding author's e-mail: Maris.Juruss@rtu.lv
}

\begin{abstract}
There is a large value added tax fraud in the European Union. The current value added tax system is universal as tax is applied to all parties involved in the chain transactions, thus creating a risk of tax losses if one of the parties involved in the chain transaction does not pay tax in good faith. There is the action plan to introduce the definitive value added tax to prevent tax fraud in intra-community transactions. However, in order to ensure normal value added tax administration in all member states, a number of measures are needed to be done. It is necessary to develop a mutual settlement mechanism in cases of intracommunity transactions. The aim of this research is to develop a possible solution for the management of tax payments under the definitive value added tax regime. The results of the research show that to manage tax payments, several payment management systems can be used. However, as a solution, a special clearing system could be introduced. Quantitative research methods such as statistical methods were used in order to analyze the situation of tax fraud in EU and its main causes, as well as mathematical modeling methods to analyze the definitive VAT system and to calculate the balance between countries in an example for clearing mechanism.
\end{abstract}

Keywords: Clearing system, definitive tax principle, tax fraud, value added tax.

\section{INTRODUCTION}

There is a significant level of trade between the European Union (hereafter EU) member states - at EUR 3110 billion in 2016. This was $78 \%$ higher than the level recorded for exports leaving the EU-28 to non-member countries of EUR 1745 billion. Intra EU-28 trade increased by $1.3 \%$ across the EU-28 between 2015 and 2016. The biggest increases in intra-EU trade in 2016 were registered for Cyprus $(11.2 \%)$, Romania (7.0 \%), and Croatia (5.7 \%). Germany was also an EU member state with the highest level of intra EU-28 trade in 2016, contributing $22.8 \%$ of the EU-28's dispatches of goods to other member states and also just over one fifth $(20.9 \%)$ of the EU-28's arrivals of goods from other member states (Eurostat, 2017).

The importance of the EU's internal market is underlined by the fact that intraEU trade in goods (dispatches and arrivals combined) was higher than extra-EU trade (exports and imports combined) for each EU member state, with the exceptions of Malta and the United Kingdom where they were very nearly balanced. The proportion of total trade in goods that was accounted for by intra-EU and extraEU flows varied considerably across the member states, reflecting to some degree 
historical ties and geographical location. The highest shares of intra-EU trade (around $80 \%$ of total trade) were recorded for Estonia, Luxembourg, Hungary, the Czech Republic, and Slovakia, with this ratio falling to $49.3 \%$ in the United Kingdom (Eurostat, 2017).

Due to the significant level of trade between EU member states, the value added tax (hereafter - VAT) fraud is one of the main problems for tax administrations. Trade amounts between EU countries get bigger and bigger every year. Because of that, also VAT fraud amount increases reaching 160 billion EUR in 2016 (Poniatowski, Bonch-Osmolovskiy, \& Belkindas, 2016).

To fight with VAT fraud, the new definitive VAT system is going to be implemented in the EU (European Commission, 2011). The main difference between the definitive VAT system and the current VAT system is that transactions between member states will be considered as the transactions within one country a single EU tax area.

The aim of this research is to develop a possible solution for tax payment management or clearing system in the new definitive VAT system in the EU. The tasks of the research are:

1) to analyze the current system and the main ways of payment, as well as tax fraud;

2) to examine how the new system could be implemented for the management of intra-tax payment;

3) to review expert opinions on taxation and cooperation between countries;

4) to develop tax payment management principles, including the clearing system for intra-community transactions.

There are some practical tax payment systems that are compatible to the definitive VAT system; however, there are no clear regulations from European Commission which system are they going to apply. This paper provides some practical options for tax payment management under the new definitive VAT system.

\section{REVIEW OF THE LITERATURE}

The current VAT system consists of a zero-rated cross-border VAT if the goods are supplied to another EU member country. However, it creates a risk for tax fraud, which is possible because of the current VAT rules and also the lack of deep and effective cooperation between tax administrations. Therefore, the European Commission is moving forwards a single VAT area in EU and has started changing the current VAT system. One of the main reasons for that is the current VAT system is not persistent against VAT fraud.

There can be many ways of VAT fraud. Frauds that can arise because of underreported sales, failure to register, misclassification of commodities, omission of self-deliveries, false accounting, and other ways (Smith \& Keen, 2007).

Most of the tax fraud is committed on cross-border transactions. Frauds distinct to the VAT: false claims for tax paid at previous stages, credit claimed for VAT on purchases that are not creditable, bogus traders. In practice, the fraud can be immensely obscured by using complex buffer operations and country routings (the 
export by firm, for example, could be to a non-EU country, since that also gives rise to refund) (Smith \& Keen, 2007).

There are many more reasons to change the system, like it is not designed to the new ways of entrepreneurship and it faces problems with the new technologies and digital world. Of course, there are mechanisms introduced to limit the fraud amount like reverse charge mechanism. But it cannot be applied to all sectors and that just complicates the whole system as a system. That is the reason why European Commission is working on the new VAT system - definitive VAT system.

The definitive VAT system is not a new principle of taxation of the VAT. It has been developed before the introduction of a single market (Smith, 1997), as well as time to time has been discussed as one of the possible directions of further harmonization of the VAT system (Lockwod, De Meza \& Myles, 1995; Smith, 1997; Vanistendael, 1995; Jennings, 2010; Haufler, 2012). However, it still has not been implemented due to the lack of political and technical consensus.

The definitive VAT system works as the intra-community transactions between traders in two different EU member countries is done as within one country. That means that this tax system is based on destination principle. The main change from the current VAT system is that there is no more tax exemption in case of intracommunity transactions if the goods are supplied to another EU member state. Consequently, intra-community transaction is charged with the VAT rate of the country destination.

The purpose of VAT system replacement is not only to avoid certain problems of the present VAT regime like VAT fraud and of compliance-based trade discrimination and of undesirable VAT revenue shifts, but also to reduce national VAT autonomy, to introduce a new international revenue sharing mechanism, and to help harmonize VAT administration in member countries. There can be options for settlement system, which could support and respect VAT autonomy for member countries, simplifying the effect for the whole VAT system (Genser, 2003). Implementing a special VAT payment management on intra-community transactions would simplify the whole process of VAT assignment to subnational governments. That means the member states will remain sovereign regarding VAT rates while destination-based taxation is used. A special VAT scheme would allow the zero rate to exporting state and the importing state to defer the payment of tax on imports from other states without breaking the chain of credits (McLure, 2000).

The purpose of EU VAT reforms should not just be intra-community fraud, the reforms should be also addressed to input tax deductions. Reverse charge mechanism is the answer to both of these problems, but it does not work if it is applied to all transactions. Implementing reverse charge mechanism in some specific sectors, on the other hand, creates a dual tax system. While all special VAT payment management systems have similar flaws, the hybrid of those systems could be the correct answer (Wohlfahrt, 2011).

The invoice-credit VAT has not yet been fully understood, but it can be powerful. In the area of financial services, for example, the work of Poddar and English (1997) has shown that it is much more straightforward than thought before. The same thing is happening in terms regarding the applicability of VAT to lower levels of governments - for example, introducing VAT as a provincial tax. Special 
VAT management systems like Viable Integrated VAT and Credit VAT provides the implementation of the new VAT system without breaking the VAT chain on interstate exports. However, there is no federal tax administration (and no willingness to create one) and that is why both of these VAT systems face difficulties ensuring that revenue collected on exports from one province is available to finance credits/refunds claimed in another.

The lower level tax system is not appropriate for all countries. Some provinces could be too small for cross-border shopping to be controlled or have the capacity problems for provincial administration to work. Also, these special VAT management systems have issues that are not resolved or developed here. However, these concepts have enough advantages to put them on tax reform agenda (Keen, 2000).

\section{CONCEPT}

In order to ensure normal VAT operation in all EU countries, a number of measures are needed to be done. It is necessary to develop a mutual settlement mechanism in cases of intra-community transactions. The system is based on the order that each country collects the VAT determined by its national law at an appropriate rate, but several conditions must be complied. However, the new system provides that the tax is to be paid at the rate of the country of destination. This causes a number of problems. Firstly, how to properly enforce tax collection. Secondly, how to transfer collected tax to the country of destination. Thirdly, how to handle different tax rates.

For the system to function, the clearing system could be adopted. Intracommunity transactions can be very different. Items are transferred from one country to another in very large amounts. In order for tax administrations not to transfer money transfers to another country, it would be logical if the balance is calculated and tax payment transfer is made to the country, which has the balance surplus (Jurušs, 1999). For example, there could be intra-community transactions between countries X, Y, and Z (Fig. 1.).

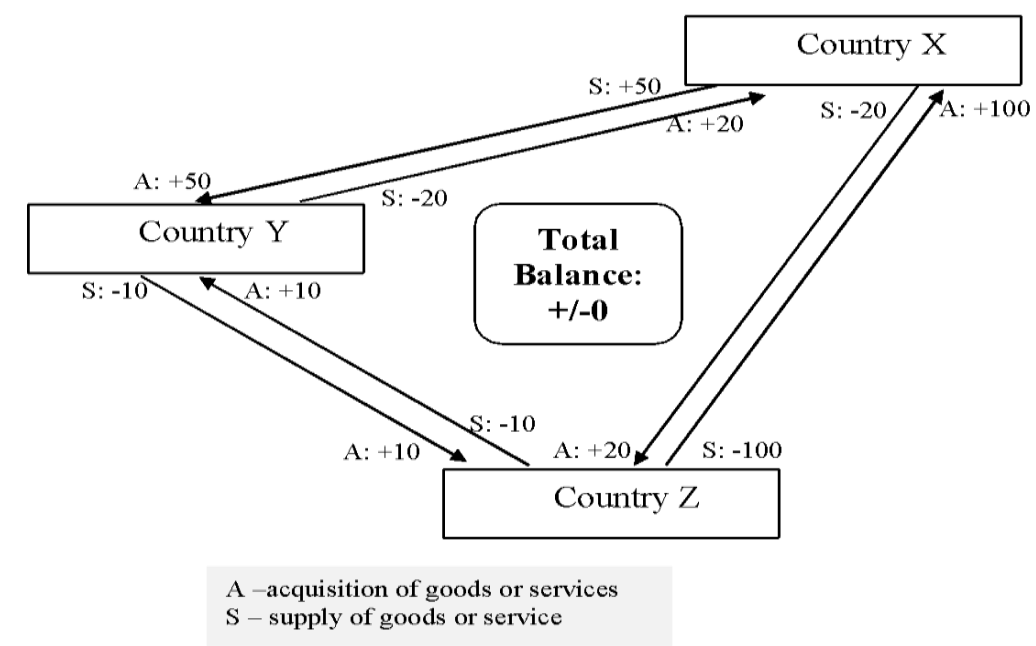

Fig. 1. Clearing system (developed by the authors). 
Figure 1 shows the mutual settlement principle between three countries with the main principle that the balance between countries must be 0 . Countries settle between themselves, and only positive balance is transferred.

Currently, intra-community transactions in each country (X, Y, and $\mathrm{Z}$ ) are subject to VAT of $0 \%$, after the goods are supplied from the country $\mathrm{X}$ to $\mathrm{Y}$ or $\mathrm{Z}$, while in country $Y$ or Z it applies reverse charge VAT at the tax rate fixed in country $\mathrm{Y}$ or Z. So, input tax is refunded in country $\mathrm{X}$, but in country $\mathrm{Y}$ or $\mathrm{Z}$ has been charged a new VAT.

In the new order, the company from country $\mathrm{X}$ will pay VAT in country $\mathrm{Y}$ or $Z$. As a result, all companies of country $X$ will pay the amount for such supplies to country $\mathrm{Y}$ or Z, which will have to be transferred to the country $\mathrm{Y}$ or Z budget. On the other hand, the same procedure will be applied to the deliveries of goods from country $\mathrm{Y}$ or $\mathrm{Z}$ to $\mathrm{X}$, which will result that VAT payed by companies in country $\mathrm{Y}$ or $Z$ will be transferred to country $X$.

In order not to make payments from one country to another, the balance could be calculated and only the positive balance could be transferred to the country in which the delivery was greater (or the largest VAT payment). So, countries settle among themselves in accordance with all international trade transactions.

In the authors' version, it is proposed to make payments on the basis of the results - each country must pay or receive money to the extent that it is due after accounting and calculation of the mutual trade transactions.

To better understand how the clearing system could work, the authors have developed formulas for calculating the VAT payment management. The basis for calculating is the total balance of payments, which could be found as the difference between the total payments of VAT for the acquisition of goods and services into the country and the total payments of VAT for the supply of goods and services from the country. Formula (1) can be used for calculation:

$$
B_{n}=\sum A_{n}-\sum S_{n},
$$

where

$B_{n} \quad-$ total balance of VAT payments for country $n$;

$\sum A_{n} \quad-$ total payments of VAT on the acquisition of goods and services into the country $n$;

$\sum S_{n} \quad-$ total payments of VAT on the supply of goods and services from the country $n$.

The total amount of value added tax due for imported goods is calculated as the sum of all VAT payments due on goods imported from other countries involved in this settlement. For example, the total VAT on goods imported into a country can be calculated as the sum of goods imported from other member states. In this case, it can be calculated according to Formula (2):

$$
\sum A_{n}=A_{1}+A_{2}+\ldots+A_{27}
$$

where

$$
\begin{array}{ll}
\sum_{A} A_{n} & - \text { total payment of VAT on the acquisition of goods in country } n ; \\
& - \text { acquisitions from the relevant member state. }
\end{array}
$$


With a similar calculation, VAT payments that are payable on goods supplied from the state are calculated. For example, the tax on goods supplied from country $n$ to other member states can be calculated according to Formula (3):

$$
\sum S_{n}=S_{1}+S_{2}+\ldots+S_{27}
$$

where

$$
\begin{array}{ll}
\sum_{S} S_{n} & - \text { total payments of VAT on supplied goods from country } n ; \\
& - \text { supply to the relevant member state. }
\end{array}
$$

Clearing system is based on the fact that the total balance or the sum must be zero. It should be noted that only a logical result can be derived from the calculation of each country's balance, that is, if a country pays to another country, then there cannot be a situation where the balance of that other country shows that this other country has to pay the first, etc. The result can be simply verified by the fact that the sum of the total balance of the payments of all countries should be equal to zero, since there can be no surplus or a balance in all mutual settlements. It can be described by Formula (4):

$$
\sum B=B_{1}+B_{2}+\ldots+B_{28}=0,
$$

where

$\sum B-$ total balance of the payments of VAT in all countries;

$B_{1} \ldots B_{28}$ - balance of the payments of VAT in the relevant member state.

\section{RESULTS}

As a result of these calculations, using Formulas (1)-(4) can be calculated, for example, if one country has to pay to another countries revenue from VAT on goods exported to these countries or has to receive VAT payments from other countries.

If the result is a negative balance $\left(B_{n}<0\right)$, this means that a country has to pay that amount to another country, but if the result is a positive balance $\left(B_{n}>0\right)$, this means that a country has to receive this amount from other countries.

Table 1. Paying balance between countries (developed by the authors)

\begin{tabular}{|c|c|r|r|r|r|}
\hline & & Country X & \multicolumn{1}{c|}{ Country Y } & Country Z & \multicolumn{1}{c|}{ Total } \\
\hline \multirow{4}{*}{$\begin{array}{c}\text { Acquisition from } \\
\text { (A) }\end{array}$} & Country X & n/a & +50 & +20 & +70 \\
\cline { 2 - 6 } & Country Y & +20 & n/a & +10 & +30 \\
\cline { 2 - 6 } & Country Z & +100 & +10 & n/a & +110 \\
\cline { 2 - 7 } & & Country X & Country Y & Country Z & Total \\
\cline { 2 - 7 } & Total A & +120 & +60 & +30 & +210 \\
\hline \multirow{4}{*}{ Supply to (S) } & Country X & n/a & +20 & -100 & -120 \\
\cline { 2 - 7 } & Country Y & -50 & n/a & -10 & -60 \\
\cline { 2 - 7 } & Country Z & -20 & -10 & n/a & -30 \\
\cline { 2 - 7 } & Total S & -70 & -30 & -110 & -210 \\
\hline Balance (B) & & +50 & +30 & -80 & 0 \\
\hline
\end{tabular}


Table 1 shows the system of the mutual management of VAT payment between countries. The example shows how countries should manage tax payment in case of intra-community transactions.

Table 1 shows the mutual payment settlement calculations between three member states: $\mathrm{X}, \mathrm{Y}$, and $\mathrm{Z}$. The main point to this calculation - balance should always be 0 at the end of the period. The Table is divided in two parts: the acquisition part from other countries, and supply part to other countries. All VAT payments done in each country are registered and taken into this calculation. Only the positive balance is transferred to the country in which the delivery was greater or in which the largest VAT payment was made. Countries afterwards settle among themselves in accordance with all international trade transactions. Each country pays or receives money to the extent that it is due after accounting and calculation of the mutual trade transactions.

\section{DISCUSSION}

Nevertheless, the clearing system does not exist in any country or union now; however, it might help develop and solve several problems of tax management under the definitive VAT system. First of all, it will reduce the risk of fraud and other illegitimate actions, as there are two countries' tax administrations involved. It simplifies VAT settlement in intra-community transactions. It will increase government revenues. Lower cash movements also require fewer banking transactions, with less maintenance costs. Cash flow is much faster because it is not necessary to pay full amount in the total budget, and then some of it must be repaid back. There is no general budget as such, only mutual settlements. There is no need for the overall budget maintainer, since only a coordinator who monitors cash flow is sufficient.

It should be noted that clearing system will not applied in cases of imports from (or exports to) other countries outside the EU. In this case, the tax in its budget should be charged in the country where the goods are imported for consumption in the case of imports, that is, in the country where the goods will be received. Exporting a product or a service to a non-EU country is subject to a $0 \%$ tax. This also applies to cases where goods are imported or exported through another EU country, only in this case, countries must agree how the product crosses that country - either by applying a tax system or by showing documents proving that the tax has been paid (taken into account) in the relevant country to which the goods are moved in the case of imports. In the case of exports from the EU outside the EU, it must be agreed by the countries that they accept the certification by other customs authorities that the goods have left the EU - customs should work for the common interest.

If there will be one single currency in the EU as the Euro, then the mutual clearing system would possibly run with this single money. However, as there are not Euro in all member states, it should be agreed about common clearing principles also for the countries outside the Euro zone.

It is necessary to agree how companies will pay the amounts of tax payable in practice and how they will be transferred from one country's budget to another. Due 
to the limited amount, the budget and money transfer issues are not covered in detail in this paper. Separate accounts may be distributed, unlike the tax payable in the country's budget, an entity could immediately pay the tax payable on mutual transactions in these accounts. Separate accounts of cash savings would also help to track and control the transactions. Some questions about tax periods also need to be resolved, that is, if tax periods differ or there is a shift in payments which may delay the transfer of money.

In any case, countries should also have a financial security fund for contingencies. This would also apply to cases when in mutual trade there are some illegal action notices and the money needs to be recovered from a company but that cannot be done.

This system can work even if there are different tax rates in the member countries. Each country from which the goods supply to another country gives back/pays back all the tax collected, even if the tax rate is higher than in other countries. In this case, the country in which the goods are imported has to repay the company a higher tax, the amount that had been paid in the country of departure of the goods, in the form of input tax. This means that the countries have to agree on this matter.

For effective control mechanism, a single database could be created for the compilation and re-examination of VAT returns. That database could be designed to automatically report the movement of goods - to inform that the product was dispatched from one country to another and whether it was also received in the country of destination.

There are many other things that need to be agreed on by the countries before the system is set up and incorporated into national legislation. The agreement could be in the form of a joint directive or other similar legally binding common law.

Problems may occur if tax rates are different and the company will have to pay a higher input tax in the original country but customers will have to pay a lower tax in the supplying country. In such cases, the situation arises that the member state of the sender is due to pay off its budget.

\section{CONCLUSION}

There are a number of things which need to be done before implementing the definitive VAT system. The current VAT system makes possibility for tax fraud in case of intro-community transactions. The main aim of the new definitive VAT system is to reduce the possibility of VAT fraud. However, it is necessary to introduce a special clearing system between the EU member states, which will reduces transaction amounts and money flow in case of intra-community transactions. It is proposed to make payments on the basis of the results - each country must pay or receive money to the extent that it is due after accounting and calculation of the mutual trade transactions. The cooperation and exchange of information about intra-community transactions should also be in place, probably a special database. 


\section{REFERENCES}

European Commission. (2011). "Green Paper" on the future of the VAT. Tax Executive, 63(3), p. 185.

Eurostat. (2017). International trade in goods. Retrieved from http://ec.europa.eu/eurostat/statisticsexplained/index.php/International_trade_in_goods\#Intra-EU_trade_in_goods

Genser, B. (2003). Coordinating VATs between EU member states. International Tax and Public Finance, 10(6), 735-752. https://doi.org/10.1023/A:1026342206742

Haufler, A. (2012). Commodity Tax Harmonization in the European Community: A General Equilibrium Analysis of Tax Policy Options in the Internal Market. Studies in Contemporary Economics. Springer Science \& Business Media.

Jurušs, M. (1999). Theoretical Aspects of Improvement of Tax System. Doctoral thesis. Riga: RTU.

Jennings, C. (2010). The EU VAT System-Time for a New Approach? International VAT Monitor, 21(4), p. 257.

Keen, M. (2000). Vivat, Cvat and All that: New Forms of Value-Added Tax for Federal Systems. IMF Working Paper No. 00/83. Retrieved from https://papers.ssrn.com/sol3/papers.cfm?abstract_id=879610

Lockwod, B., De Meza, D., \& Myles, G. (1995). On the European Union VAT Proposals: The Superiority of Origin over Destination Taxation. Fiscal Studies, 16, 1-17. Retrieved from http://people.exeter.ac.uk/gdmyles/papers/pdfs/ECOANDD.pdf

McLure, C. (2000). Implementing Subnational Value Added Taxes on Internal Trade: the Compensating VAT (CVAT). $\quad$ Retrieved http://citeseerx.ist.psu.edu/viewdoc/download?doi=10.1.1.199.8913\&rep=rep1\&type=pdf

Poniatowski, G., Bonch-Osmolovskiy, M., \& Belkindas, M. (2016). Study and Reports on the VAT Gap in the EU-28 Member States: 2016 Final Report. EC. Retrieved from https://ec.europa.eu/taxation_customs/sites/taxation/files/2016-09_vat-gap-report_final.pdf

Poddar, S., \& English, M. (1997). Taxation of Financial Services under a Value-Added Tax: Applying the Cash-Flow Approach. National Tax Journal, 50(1), 89-112.

Smith, S. (1997). The Definitive Regime for VAT. Retrieved from https://www.ifs.org.uk/comms/comm63.pdf Smith, S., \& Keen, M. (2007). VAT Fraud and Evasion: What Do We Know, and What Can be Done? Retrieved from http://www.imf.org/en/Publications/WP/Issues/2016/12/31/VAT-Fraud-and-Evasion-What-Do-WeKnow-and-What-Can-be-Done-20215

Vanistendael, F. (1995). Proposal for a Definitive VAT System Taxation in the Country of Origin at the Rate of the Country of Destination, without Clearing. EC Tax Review, 4, 45-53.

Wohlfahrt, B. (2011). European Union -The future of the European VAT system. International VAT Monitor, 22(6), 387-395. Retrieved from http://empcom.gov.in/WriteReadData/UserFiles/file/No_6\%20A-4.pdf

\section{AUTHORS' SHORT BIOGRAPHIES}
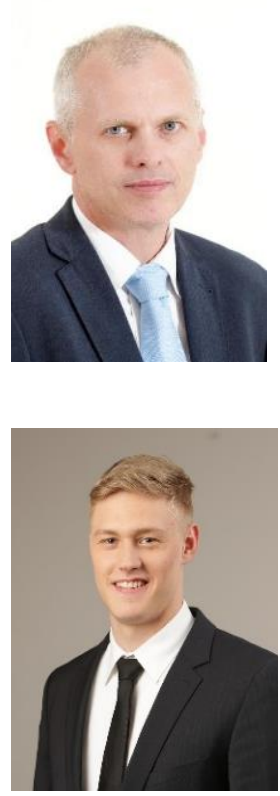

Māris Jurušs, Dr. oec., is an Assistant Professor at Riga Technical University (RTU). He received the Ph.D. degree in engineering economics from RTU in 1999. He has made the research project "Theoretical Aspects of Improvement of Tax System". From 1996 to 2007, he was with the Ministry of Finance. He has been involved in various working groups of the European Commission and Council during Latvian tax legislation harmonization with the EU principles. From 2007 to 2012, he worked as a Tax Manager for PricewaterhouseCoopers. M. Jurušs has been involved in several researches and many tax projects regarding excise duty, customs matter, and others. E-mail: Maris.Juruss@rtu.lv

Girts Feldbergs received the B.S. degree in business logistics from the Faculty of Engineering Economics of Riga Technical University (RTU) in 2016. He is currently a Master's degree student in customs and tax administration at RTU.

E-mail: Girts.Feldbergs@inbox.lv 